\title{
Effects of revibration on early age retarded concrete
}

\author{
M. M. Kassim \\ College of Eng., Civil Eng. Dept., University of Kirkuk, Iraq
}

\begin{abstract}
In this study, the influence of revibration on the compressive strength of retarded concrete is examined at late lag time intervals before and after the initial and final setting times. The time lag intervals ranged from about $2 \mathrm{hrs}$ to $8 \mathrm{hrs}$ and the retarder dosages of the used cement weight ranged from $0.5 \%$ to $1.5 \%$. Results from this study indicate that the maximum compressive strength is achieved when the concrete is revibrated after $2 \mathrm{hrs} 35 \mathrm{~min}$ with $0.5 \%$ of retarder dosage for any workability. Furthermore, higher dosages of the retarder do not reduce the compressive strength of the concrete when it is revibrated at late lag time intervals even near its final setting time. The use of setting retarder in high doses and revibration of the concrete reduces the air-voids in hardened concrete. Keywords: revibration, retardation, workability, fresh concrete, compressive strength.
\end{abstract}

\section{Introduction}

It is essential to place concrete continuously to avoid cold joints in structures such as beam-column intersection and large constructions (bridge decks and turbine foundations). In these types of structures, micro transverse cracks could form in the fresh concrete because of the changes in deflection and rotation over supports during construction due to the dead weight of the concrete. Additionally, theses cracks might result from a lapse in time between revibration and the final setting of the earlier poured layers of concrete. (CCAA Report [1] and Krishna et al. [2]).

Previous studies indicate that revibration improves many of the qualities of hardened concrete since it is carried out within about 4 hours from the mixing time. Compressive strength increases approximately 14\%. Water tightness and 
concrete density are greater and there is an improvement in the appearance of the formed surfaces [3, 4].

The primary chemical process that occurs in the first 2 hours after concrete placement is the formation of calcium hydroxide, which typically makes up 15 to 25 percent of the ordinary Portland cement concrete. The other major product of hydration is calcium silicate hydrate, which is approximately 50 percent of the ordinary Portland cement concrete and gives the concrete its hardness and durability. Calcium silicate hydrate forms quickly after several hours. Formation of the more brittle, weaker calcium hydroxide continues but falls behind the calcium silicate hydrate formation, which accelerates dramatically between initial set and final set. Therefore, revibration of concrete after the initial set has an advantage of momentarily liquefying the concrete again and break down some of the weaker calcium hydroxide that already formed. This allows freshly placed concrete adjacent to the revibrated concrete to form a monolithic concrete structure, rather than introducing a construction joint [5].

Concrete benefits from revibration when concrete is plastic enough to permit the vibrator to sink on its own. After the final set of concrete takes place, the vibrator takes 30-60 seconds to sink in the concrete. This delay in revibration may reduce the strength of hardened concrete [6,7]. At this interval of time, the revibration effect on concrete strength has not sufficiently been investigated.

Retarded concrete remains in plastic phase much longer than plain concrete. Therefore, the delay between placement and revibration could increase. Also the retarder plasticizer improves the compressive strength of plain concrete revibrated at late period after placing $[8,9]$.

This study quantifies the change in compressive strength of concrete revibrated indirectly with a table vibrator using different parameters namely lag time intervals (2-8 hours) and retarder plasticizer doses $(0.5-1.5 \%)$.

\section{Experimental program}

To study the effect of indirect revibration on compressive strength of retarded concrete using different retarder plasticizer dosages and time lag intervals. Sets of compressive strength tests on concrete cube specimens $150 \mathrm{~mm}$ carried out; each set consisted of three specimens. Concrete of four different properties was used based on different retarder dosages $(0.0 \%, 0.5 \%, 1.0 \%$, and $1.5 \%)$. Six time lag intervals were used for revibration, namely, $0 \mathrm{hrs,} 2 \mathrm{hrs} 35 \mathrm{~min}$ (one hour before initial setting time), $3 \mathrm{hrs} 35 \mathrm{~min}$ (at initial setting time), $5 \mathrm{hrs} 40 \mathrm{~min}$ (one hour before final setting time), $6 \mathrm{hrs} 40 \mathrm{~min}$ (at final setting time), and $7 \mathrm{hrs}$ $40 \mathrm{~min}$ (after one hour from final setting time).

\subsection{Materials}

Cement: An ordinary Portland cement was used produced locally by Kirkuk Cement factory in accordance with Iraqi Specification [10]. Details of the chemical and physical properties are shown in Tables 1 and 2 respectively. 
Table 1: $\quad$ Chemical composition of the ordinary Portland cement (O.P.C.).

\begin{tabular}{|c|c|c|}
\hline Property & Test result, $\%$ & Standard IQS, No. 5 \\
\hline \multicolumn{3}{|l|}{ 1. Oxide composition } \\
\hline Alumina, $\mathrm{Al}_{2} \mathrm{O}_{3}$ & 5.1 & \\
\hline Silica, $\mathrm{SiO}_{2}$ & 21.89 & \\
\hline Ferric Oxide, $\mathrm{Fe}_{2} \mathrm{O}_{3}$ & 3.4 & \\
\hline Lime, $\mathrm{CaO}$ & 63.11 & \\
\hline $\begin{array}{l}\text { Sulphate Anhydride, } \\
\mathrm{SO}_{3}\end{array}$ & 2.22 & Max. $2.5 \%$ \\
\hline Magnesia, $\mathrm{MgO}$ & 3.04 & Max. 4\% \\
\hline \multicolumn{3}{|c|}{ 2. Compound composition } \\
\hline $\mathrm{C}_{3} \mathrm{~A}$ & 7.77 & \\
\hline $\mathrm{C}_{2} \mathrm{~S}$ & 29.00 & \\
\hline $\mathrm{C}_{3} \mathrm{~S}$ & 45.03 & \\
\hline $\mathrm{C}_{4} \mathrm{AF}$ & 10.34 & \\
\hline
\end{tabular}

Table 2: $\quad$ Physical properties of the O.P.C.

\begin{tabular}{|l|l|l|}
\hline Property & Test result & Standard IQS, No. 5 \\
\hline Fineness (Residue on sieve NO. 170) & ----- & Max. $10 \%$ \\
\hline Specific surface "Blaine," $\mathrm{cm}^{2} / \mathrm{gm}$ & 3348 & 2250 \\
\hline Initial setting time, min. & 217 & Min. 45 minutes \\
\hline Final setting time, min. & 400 & Max. 10 hours \\
\hline Compressive strength, MPa. & 26.79 & $15 \mathrm{MN} / \mathrm{m}^{2}$ \\
\hline At 3 days & 36.21 & $23 \mathrm{MN} / \mathrm{m}^{2}$ \\
\hline At 7 days &
\end{tabular}

Fine aggregate: River sand with a maximum size of $4.75 \mathrm{~mm}$ conforming to zone II of British Standards (BS 882: 1992) [11] was used, as detailed in Table 3.

Table 3: $\quad$ Characteristics of fine aggregate.

\begin{tabular}{|l|l|l|}
\hline Sieve Size $(\mathrm{mm})$ & $\%$ passing & $\begin{array}{l}\text { Limits Zone II as per B.S 882, } \\
\% \text { passing }\end{array}$ \\
\hline 9.5 & 100 & 100 \\
\hline 4.75 & 100 & $90-100$ \\
\hline 2.36 & 77.5 & $75-100$ \\
\hline 1.18 & 64.5 & $55-90$ \\
\hline 0.6 & 53.1 & $35-59$ \\
\hline 0.3 & 28.9 & $8-30$ \\
\hline 0.15 & 8.6 & $0-10$ \\
\hline Fineness Modulus 2.67 \\
\hline
\end{tabular}


Coarse aggregate: Normal river gravel was used (irregular almost rounded maximum size $20 \mathrm{~mm}$ ) in accordance to BS 882: 1992 [11]. Their sieve analysis and grading are shown in Table 4.

Table 4: $\quad$ Characteristics of coarse aggregate.

\begin{tabular}{|l|l|l|}
\hline Sieve Size $(\mathrm{mm})$ & \% Passing & $\begin{array}{l}\text { Limits as per B.S 882 } \\
\% \text { passing }\end{array}$ \\
\hline 37.5 & 100 & 100 \\
\hline 20 & 95 & $85-100$ \\
\hline 10 & 22.9 & $0-25$ \\
\hline 5 & 1.4 & $0-5$ \\
\hline \multicolumn{2}{|l}{ Fineness Modulus 6.81 } \\
\hline
\end{tabular}

Water: Ordinary potable water was used for mixing and curing purposes.

Chemical admixture: Sika-retarder was used to meet a highly efficient setretarding admixture, which properties are shown in Table 5.

Table 5: $\quad$ The properties of Sika retarder.

\begin{tabular}{|l|l|}
\hline Type & Naphthalene formaldehyde sulphonate \\
\hline Colour & Transparent liquid \\
\hline Density & $1.2 \mathrm{~kg} / \mathrm{l}$ \\
\hline Dosage & $0.2-2.0 \%$ by weight of cement as retardation rate is required. \\
\hline
\end{tabular}

\subsection{Mix Proportions and procedure}

The mixes were prepared with four different retarder admixture ratios, $0 \%, 0.5 \%$, $1 \%$ and $1.5 \%$ of cement weight. The cement and $\mathrm{w} / \mathrm{c}$ ratios were kept constant at $400 \mathrm{~kg} / \mathrm{m}^{3}$ and 0.425 respectively for all of the tested mixes as shown in Table 6. The control mix was designed by ACI method [12].

All mixes were prepared in an electrical mixer. The mixing sequence consisted of homogenizing the coarse and fine aggregate and cement for an adequate time. The Sika retarder and water was mixed and added to admixture and mixed again properly until a uniform admixture was obtained [13]. Once the mix was prepared, the slump test was performed in a quick succession, according to ASTM C143/ C143M-05a [14], to determine the workability.

\subsection{Casting and testing}

Cube specimens of $150 \mathrm{~mm} \times 150 \mathrm{~mm} \times 150 \mathrm{~mm}$ were cast as per the standard procedure. Westerwork $300 \mathrm{~mm}$ x $600 \mathrm{~mm}$ balance vibrating table with 3000 rpm was used for initial vibrating and revibration of the concrete. The casting of the cubes was done in three layers. The first two layers were vibrated for 20 seconds and the last third layer vibrated for 40 seconds. In lag interval times the casted concrete was revibrated again for 40 seconds. The compressive strength of the specimens at the end of 28 days curing in water was tested using ADR 1500 ELE Testing Machine under strain rate control. 
Table 6: $\quad$ Mix characteristics of investigated concretes.

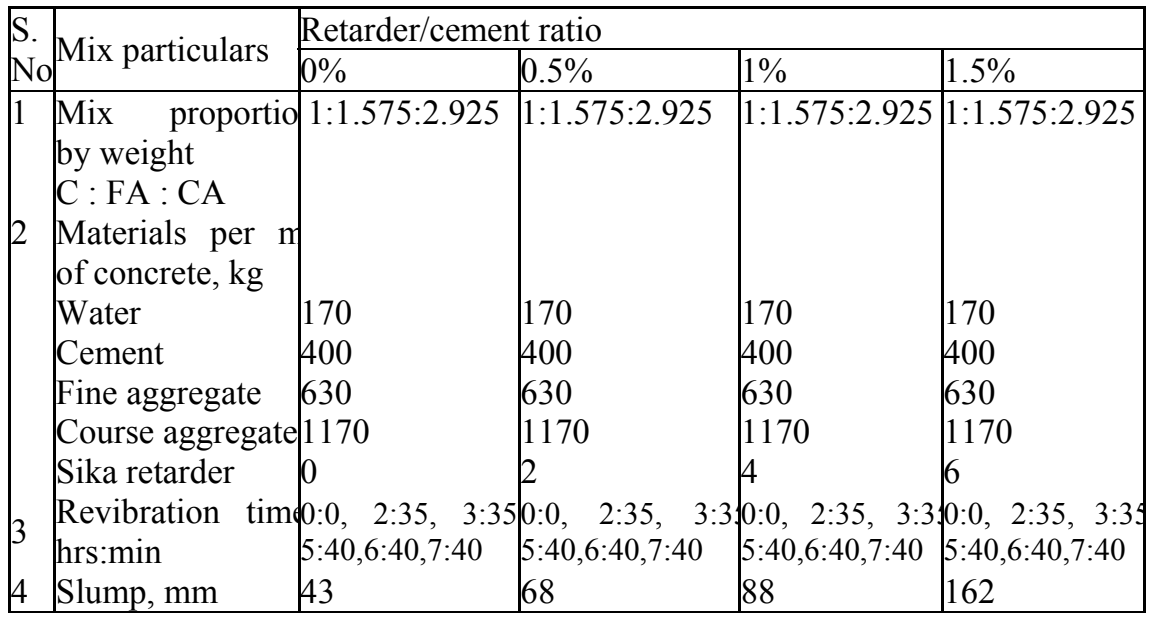

\section{Results and discussion}

\subsection{Initial and final setting time}

The influence of Sika retarder doses on the initial and final setting times of concrete is illustrated in Figure 1. It can be seen that Sika retarder doses increases the initial and final setting times. This figure also shows that the initial setting time is more affected with increasing the retarder ratio than the final setting time. Even though both of the initial and final setting times were closely related and highly affected. The maximum increases in the initial and final setting times are observed to be $414 \%$ and $238 \%$ respectively.

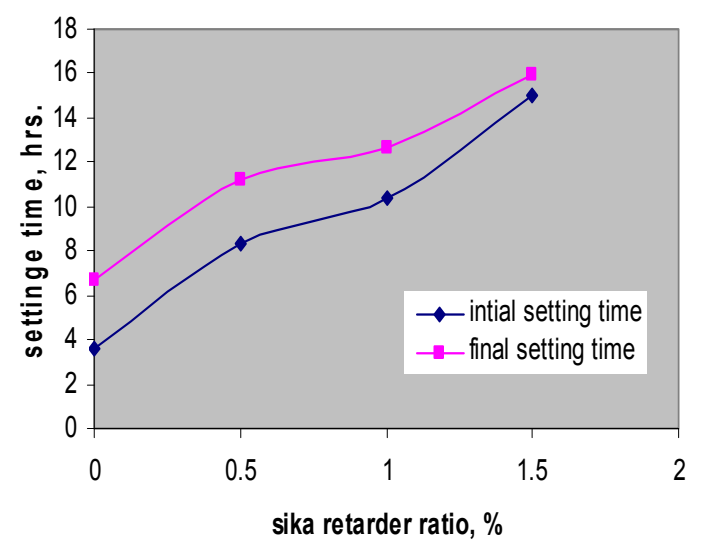

Figure 1: Effect of Sika retarder plasticizer on initial and final setting time. 


\subsection{Workability}

The relationship between the workability and Seka retarder dosages are plotted in Figure 2. The results show that the slump values have a normal linear increase for retarder ratios up to $1 \%$ of the cement weight. A significant increase in the workability is observed for dosages greater than $1 \%$ of the retarder. At the same time, this high increase in the workability was accompanied with a decrease in compressive strength at 28 day age. Therefore, the $1 \%$ ratio is the optimum effective dosage suggested to be used.

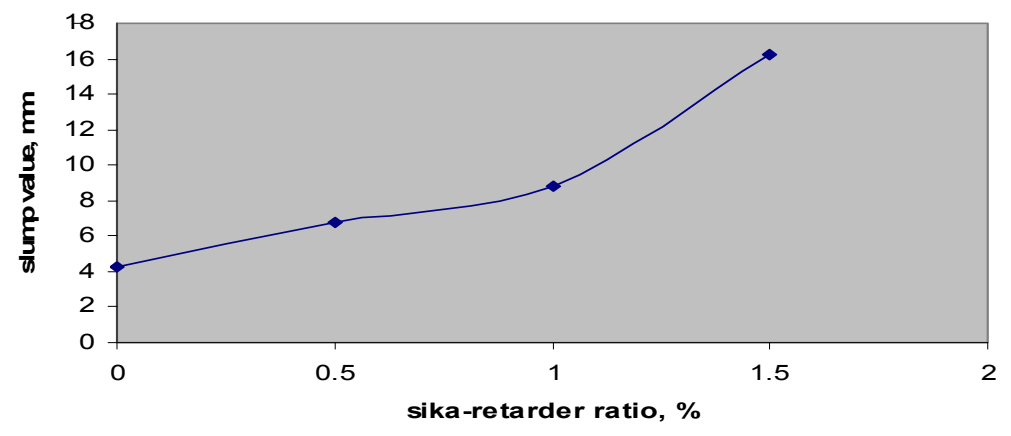

Figure 2: Effect of Sika retarder plasticizer on concrete workability.

\subsection{Compressive strength}

The compressive strength of concrete for different time lag intervals of revibration and different dosages of Sika retarder are plotted in Figures 3 and 4 respectively. A comparison of maximum percentage increase in compressive strength at a certain time lag interval for different dosages of Sika setting retarder is illustrated in Table 7 and plotted in Figure 5. From Figure 3 it can be seen that the 28 day compressive strength is slightly affected by using different dosages of Sika retarder. In general, it is known that the early age compressive strength must decrease when setting retarder is added to the mixture. This decease is related to the delay of final setting time, which is clearly noticed in figure 1, and finally delays the hardening of the concrete.

Figures 4 and 5 demonstrate that with a low retarder ratio $(0.5 \%)$ the compressive strength of the revibrated concrete increases for all revibration time intervals considered in this study. With retarder ratios more than $0.5 \%$, the compressive strength starts to decrease. This decrease in the compressive strength may be attributed to the excessive delay in setting time caused by the retarder. It is noted, however, that the compressive strength of revibrated concrete at late time intervals (at the final setting and one hour later) retains its tendency to increase with the maximum retarder ratio $(1.5 \%)$ used. This increase 
may be seen more clearly when the concrete is tested at late ages, i.e. more than 28 days. The optimum revibration time lag intervals for obtaining maximum possible percentage increase in compressive strength with retarder dosage ratios are given in Table 7.

Table 7: Increase in compressive strength and optimum time for different retarder dosages.

\begin{tabular}{|l|l|l|l|}
\hline S. No & $\begin{array}{l}\text { Retarder dosage, } \\
\%\end{array}$ & $\begin{array}{l}\text { Maximum increase in } \\
\text { compressive strength, \% }\end{array}$ & $\begin{array}{l}\text { Optimum time lag } \\
\text { interval, hrs:min }\end{array}$ \\
\hline 1 & 0.0 & 2.86 & $2: 35$ \\
\hline 2 & 0.5 & 12.34 & $2: 35$ \\
\hline 3 & 1.0 & 4.65 & $2: 35$ \\
\hline 4 & 1.5 & 7.55 & $7: 40$ \\
\hline
\end{tabular}

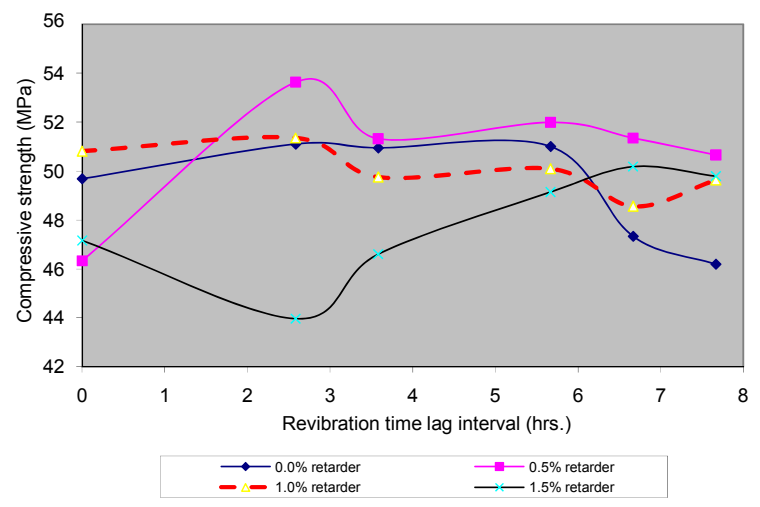

Figure 3: Compressive strength versus revibration time lag.

The additional bleeding and resettlement of revibrated concrete may occur at lag time intervals up to $3 \mathrm{hrs}$ and $35 \mathrm{~min}$, i.e., before the initial setting time, with $1 \%$ and $1.5 \%$ of the retarder. The bleeding and resettlement of concrete increases its compressive strength.

Figure 5 shows that the compressive strength of concrete without the retarder agent decreases by about $7 \%$ when revibrated at late time interval i.e. one hour after the final setting time of the used cement. 


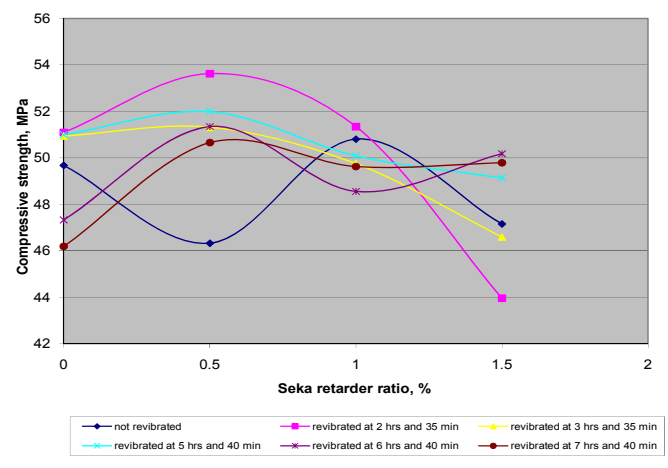

Figure 4: Effect of retarder ratios on compressive strength at different revibration time lags.

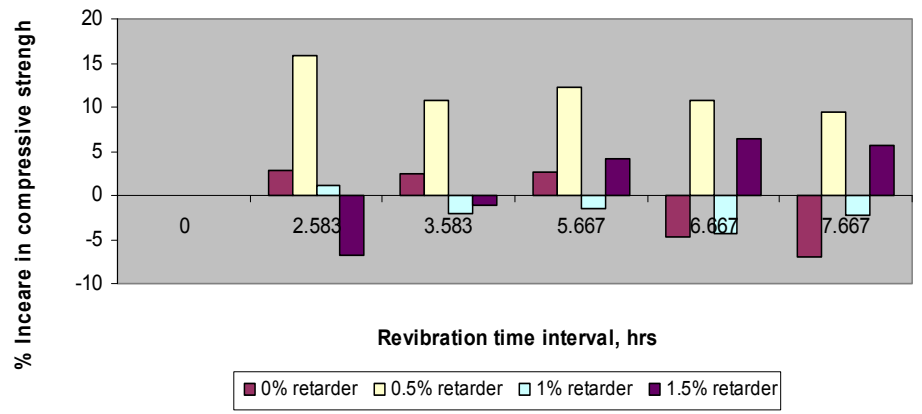

Figure 5: $\quad$ Effect of revibration time on compressive strength.

\section{Conclusions}

Based on the experimental results of this study, the following basic conclusions can be drawn:

1. The revibration of concrete can be performed at late lag time intervals with different dosages of setting retarder. The lag of time may reach the final setting time of the used cement.

2. The compressive strength of retarded concrete does not improve significantly by revibration.

3. By revibration of concrete the air-voids reduce noticeably in size and number. 


\section{References}

[1] CCAA Report. Compaction of concrete. Cement Concrete \& Aggregates Australia, June, pp. 7, 2006.

[2] Krishna Rao M.V., Rathish Kumar P. and BalaBhaskar N.V.R.C. Effect of re-vibration on compressive strength of concrete. Asian journal of civil engineering (Building and Housing) Vol. 9, No.3, pp. 291-302, 2008.

[3] Vollick C. A. Revibration produces better concrete. Concrete Construction Magazine, February, 1959.

[4] Bustani S. A., Achuenu, E. Strength properties of revibrated concrete. Nigerian journal of construction technology and management, Vol. 2, No.1, 1999.

[5] Too late to revibrate? Problem Clinic, Concrete Construction, March, 2004.

[6] Gambhir ML. Concrete Technology. Published by Taha McGraw-Hill, pp. 292-296, 2004.

[7] Dunham M. R., Rush A. S., and Hanson J. H. Effect of induced vibration on early age concrete. ASCE, Vol. 21, Issue 3, pp. 179-184, (May / June ), 2007.

[8] Hiilsdorf H. K., Lott J. L. Revibration of retarded concrete for continuous bridge decks. Highway Research Board Nchrp Report No.106, 1970.

[9] ACI Committee Report 212.4R-94.Guide for the use of high-range waterreducing admixtures (superplasticizers) in concrete, ACI Manual of concrete practice, Part 1: Materials and General properties of Concrete, 8 pp. (Detroit, Michigan), 1994.

[10] IQS.No.5. Iraqi specification for cement, 1985.

[11] B.S 882:1992, Specification for aggregates from natural sources for concrete, London, 1992.

[12] ACI 211.1-91.Standard practice for selecting proportions for normal, heavyweight, and mass concrete. ACI Manual of concrete practice, Part 1: Materials and General properties of Concrete, 38 pp. (Detroit, Michigan), 1994.

[13] Paul Klieger, Joseph F. Lamond. Significance of tests and properties of concrete and concrete-making materials. ASTM Publication Code Number (PCN) 04-169030 -07, pp. 107, 1994.

[14] ASTM C143/ C143M-05a.Test method for slump of hydraulic-cement concrete, 2005. 